\title{
WOMEN'S PARTICIPATION IN DECISION MAKING STRUCTURES AND PROCESSES: A CASE STUDY ON THE LOCAL GOVERNMENT INSTITUTION IN BANGLADESH
}

\author{
Mahanambrota Das ${ }^{1}$ \\ Nazmun Nahar ${ }^{2}$ \\ Asib Ahmed ${ }^{3}$ \\ Rajasree Nandi ${ }^{4}$
}

\begin{abstract}
Since 1976, women's participation has been empowered as part of the development discourse for achieving sustainable development in Bangladesh. Women's empowerment in the local government structures and processes has a substantial influence on the National Gender Policy of Bangladesh. This study has critically assessed the extent of the women's participation in the decisionmaking processes of the Local Government Institutions (LGIs) through participants' observation, qualitative and quantitative methods. The study evolves the success and failure attempts of the women's participation in the LGI's structures and decision-making processes as per Local Government (Union Parishad) Act-2009. The study also finds the UPs are too politicized to make them socially inclusive, pro-poor friendly and distribute equally the benefits of aids and social safety net services. The centralized power of UP chairs, manipulation and tokenism practices in the UP's governance and decision-making processes had diminished the gender sensitivity, transparency, and accountability of the institution. The study also suggests increasing the number of women representatives in UP's structures, making functional the roles of woman's vice-chair, activating the Ward level meetings, standing committees and project implementation committees, as well as regularizing the effective monitoring with transparent and accountable manner for making the UP gender responsive and people oriented.
\end{abstract}

1 Mahanambrota Das is Head, Research and Advocacy Cell, Shushilan, a Non-Government Organization, Bangladesh. E-mail: dashmahanam@gmail.com

2 Nazmun Nahar, PhD is Professor, Department of Geography and Environment, University of Dhaka, Bangladesh. E-mail: nazmun.geoenv@du.ac.bd

3 Asib Ahmed, PhD is Assistant Professor, Department of Geography and Environment, University of Dhaka, Bangladesh. E-mail: asib01geo@du.ac.bd

${ }^{4}$ Rajasree Nandi is Assistant Professor, Institute of Forestry and Environmental Sciences, University of Chittagong, Bangladesh. E-mail: rajasree@cu.ac.bd

Social Science Review [The Dhaka University Studies, Part-D], Vol. 37, No. 2, December 2020 
Keywords: decision-making process, local government institutes, women's participation.

\section{Introduction}

In Bangladesh, about half of the whole population comprises of women (Bangladesh Bureau of Statistics, 2011). Women are comparatively in an inferior position in all spheres of life, however, politically they are situated in a negligible state in the local government (Qadir, 1995). In the constitution of Bangladesh, each human being's right is guaranteed. It is also ensured that men and women, as citizens, have equal rights in the state and public life. Constitutionally, there is no distinction between man and woman in enjoying political rights. Nonetheless, individuals make discrimination within gender and give priority to men to women in the real life due to psychological internalization. The participation of women in political decision-making and power roles remains exceptionally marginal. As of now, very few Bangladeshi women can be found in positions of political leadership and administrative hierarchy in both central and local government structures. Women have a minimal impact on the planning, management, and implementation of policies and rules due to lack of access to intervene the decision-making process (Mahtab, 2007).

Systematic engagement of women in the development process improves the equitable premise, the democratic basis, the efficiency, and the quality of the activities of local government. If local government is to meet the needs of both women and men, it must build the foundation on the practices of both women and men, through a rational representation at all levels and in all areas of decisionmaking, covering the wide range of responsibilities of local government. Women's role in decision-making process is one of the critical questions for strengthening their empowerment. Keeping in mind, the importance of women's participation in decision-making process of development, just like the other government within the world, the government of Bangladesh has started efforts to broaden the scope of women (Khan \& Fardaus, 2006). Union Parishad (UP) as a unit of rural local government of Bangladesh, is the most popular democratic institution at the grassroots level. Despite encountering huge challenges, some women representatives have performed their roles with their obliged support within the UP. Therefore, sustainable, and participatory development of the grassroots level might not be achieved without drawing special consideration to 
women's benefit (Rahman, 2015). Lack of women's engagement in power and decision-making is gravely liable for socio-economic and sustainable development. Women's participation in the national and local government is called for as an encounter and experience.

The Five-Year Plans of Bangladesh also iterate policies for women's development (Akhter \& Chowdhury, 2005). Women representatives in the UP, the focal point of local government in the rural areas of Bangladesh, are for the first time elected directly within the reserved seats. This has opened an avenue for women to take part in control and make decision in the process of local government with their own possess motivation. Although this participation is in some cases to some extent barred, it provides for maintaining the interests in a pluralistic society coming about social integration (Jahan, 1997). The elected representatives at UP level are, however, mostly unaware about the benefits of participatory development approach. Lack of information and knowledge on their part, may have contributed to their misconception and misguided judgement in this respect. The poor and the disadvantaged, characterized by social, economic, and political backwardness, are habitually, socially, and technically excluded in the planning and implementation of development projects. The main contention behind people's participation in development is that genuine development must be people cantered. For instance, projects were considered and executed jointly by the local government and external organizations, but fizzled because of unsatisfactory local participation (Jazairy, 1989). Besides, the government encourages women to connect legislative and political issues since it accepts that women are enabled to participate in decision making equally with men (Karmaker, 2006).

After receiving the rights of participation of women in Union Parishad elections in 1997, 2003, 2011 and 2015-16, the number of women who participated in elections for the first time and elected most did not receive encouragement support to run another term more. Possible reasons could be that roles and responsibilities were not clearly defined, lack of gender sensitivity, lack of support from man colleagues and working environment. Another reason was that educated and conscious women did not appear intrigued in local politics and local government election. Extensive research found that the participation of woman representatives in the development activities particular to infrastructure work is being discouraged by man counterparts. The participation of man representatives 
in economic development programs such as poverty reduction, road construction, sanitation, education, and disaster management were higher than woman counterparts. On the other hand, the woman representatives' participation was comparatively higher on social safety net programs such as Vulnerable Group Feeding (VGF) card, aging card, and more.

\section{Background of the Study}

In simple words, participation is a process to mobilize and empower the community, share control over priority setting, manage the resources, influence the decisions and policymaking, and access to public goods and services. As a concept, it is not completely new; in fact, it is as longstanding as human progress (Haque, 2003). Various agencies, practitioners, specialists, and academics have characterised it from distinctive point of view. To begin with, the concept came as a concept of people's participation. Accordingly, the issue of people's participation has gained momentum in the realm of public administration and international development discourse in the last three decades. The researchers and professionals of social and political science have considered people's participation as a critical part of democracy and socio-economic development in both developed and developing countries (White, 1994; Rahman, 2000; Peters, 2001; Roberts, 2004). Over times, literature evolve in the conceptual and a theoretical definition of people's participation. Likewise, some researchers suggest that participation may be viewed from two essential hypothetical points of view; political and developmental. In the ultimate analysis, participation may be described as a political and decision-making phenomenon; as a vibrant collective activity of people in decision-making, influencing decisions, and accessing benefits from the development process (Cohen \& Uphoff, 1977).

It is usually assumed that local government was the basic form of government in the subcontinent until the $6^{\text {th }}$ century B.C. (Siddiqui, 1994). To make it adoptable, the historical basis of local government and its five stages of division must be considered (Talukdar, 2009): (a) Buddhist and Hindu Ruling Period (2300 Years dated back), (b) Muslim Ruling Period (1206-1765), (c) British India Ruling Period (1757-1974), (d) Pakistan Period (1947-1971) and (e) Bangladesh Period (1971-till date). It is difficult to identify the antiquity of institutions at local level, but it is assumed that village government existed in Vedas period. The existence of village self-government has also been identified in Quatilaya's Arthashastro, a 
very ancient book (Boesche, R. 2003). This evidence indicates how old the various village institutions are. In every village, there were local institutions in different names as Gramin, Gramika, Grampala, Panchayet, Majlish, Sabha, and Sommittee etc. (Banglapedia, 2019). Despite lacking any legal status, those various institutions of villages were respected and obeyed by all villagers. By evaluating the history, the existence of Headman (Pradhan) in the village was also traced out who was generally nominated from the powerful families of the village. He was also responsible for contacting the central authority by collecting taxes. In the above-mentioned time, there were structural differences in headmen and panchayet system. Muslim rulers started to rule the Bengal by defeating the ruler of Senas. At that time, procedure of conducting village administration was as same as the ancient period except for some minor changes. However, the traditional continuity of ancient village administration system steadily declined due to commencement of British ruling. During the British regime, local government remained an almost elite space of men that excluded gender inclusion and diversity. Only man could vote in election for rural local bodies until 1956 when, for the first time, election was held based on universal adult franchise (Alam, 1995).

In 1976, women's rights to franchise in local government was established lawfully by the declaration of the Local Government Ordinance for a three-tier local government system in Bangladesh. In this ordinance, for the first time, women were included in the Union Parishad with making the provision in selecting two women representatives. In 1983, the Local Government (Union Parishad) Ordinance made the changes into the structure and composition of the Union Parishad with the improvement of three nominated women representatives and each of them would represent one big Ward that comprises of three small Wards. In 1993, Local Government (Union Parishad) (Amendment) Act omitted the system of nomination and created the provision for indirect election of selecting three women representatives (Ahmed, 2003). As a turning point in the history of women empowerment in Bangladesh, the Local Government (Union Parishad) Second Amendment Act, 1997 was revised and was enacted the law for direct elections to reserve seats for women in local level elections. Apart from the reserved seats, women can also contest for any of the general seats (ADB, 2001). The Government introduced the Local Government (Union Parishad) Act, 2009 which came into effect on October 15, 2009 including 108 articles. In this Act, the Union Parishad consists of a chairman and twelve UP members, 
including three seats exclusively reserved for women. As per UP Act-2009, UP representatives, including UP chairs, man and woman representatives serve the UP full time and receive honorarium from the government. According to the UP Act 2009, the government encourages the bottom-up approach for taking all decisions of UP from a majority vote with the engagement of the grassroots level community and women. One-third of the positions including chairperson within the Standing Committees (SC) and Project Implementation Committees (PIC) is reserved for the woman representatives. As one of the milestones, the UP Act 2009 creates the provision for Ward Shava (Ward Meeting) as a general assembly at the grassroots level people's participation and make a universal consensus to all major decisions of UP with transparent and accountable manner where woman representatives of reserve seats will play a role as an adviser. Most critically, the Act introduces some other distinctive, important elements to UP functions including a transparent and accountable budgetary process, project's plan, and implementation for accessing the public to discussion session, prompting good governance, and creating a sense of greater local ownership.

The problem of women's participation in local government is factually and inherently political. Moreover, in the last local government (Union Parishad) elections (2015-16), UP chairmen have been nominated by the political parties although other UP members' nomination were non-political. In the study area, women members contested at all these levels of UP, but success or wining in the different positions against contest of men counterparts are very negligible. Thus, they need to understand the political process and economic empowerment. Although there is the Local Government (Union Parishad) Act-2009, formation and management of various committees of UP (such as SC, Ward Shava, PIC, etc.) are often captured and reshaped by the UP chairmen and influential (Das, 2016). It is often assumed that management practices are driven by Government circular and monitored by government officials (such as Upazila Nirbahi Officer, District Commissioner and Deputy Director of Local Government) (Das, 2016). The things deemed as 'good circular' and 'good Act' for involving women in different committees and activities of standing committees and project implementation, however, the reality is that all members are chosen through top down. For instant, participation of women and community is politically manipulated and technically captured by the influential due to create the opportunity of the leakage and the benefits of the interests. Sometimes, conflict of interests is seen between UP chairmen, men, and women UP members for 
implementation of the projects and distribution of the social safety net (Das, 2016).

\section{Rationale of the Study}

Following the Local Government (Union Parishad) Act 2009, the Union Parishad consists of a chairman and twelve UP representatives, including three seats exclusively reserved for women. UP also has power of local resource mobilization, budgeting, tax assessment and collection and fund raising from different sources for playing a vital role in local development, good governance, and women empowerment. Despite 145 (1870 to 2015) years, a long-time of local government history, significant improvement concerning women's representation took place within the last 18 years (1997 to 2015). However, within these two decades, women UP members struggled to ensure their participation and rights in the UP's decision-making process. The Union Parishad remains weak due to the overshadowing dark cloud of inefficiency, lack of resources, lack of women's participation and pervasive political corruption resulting in a low level of confidence of the people in it. The functions of the different standing committees, Ward level committees, coordination committee of Union Parishads are the main institutional avenues for the people's participation in the local decision-making process. However, these committees are not functional, and women UP members are not getting access in the structure and process of UPs due to lack of awareness, lack of capacity, politicization, and corruption. Women are not getting benefits from the development activities of local government. Besides, gender equality and women's empowerment in rural infrastructure development, repairing works and social safety net programs is very poor. Sometimes, governance has been failed and sustainable development has been redundant for nominal and manipulative participation of women and community. Hence, the present research attempted to identify the current position of women in the decision-making processes at local level and their associated problems. Moreover, the study also analysed the nature of transformation of their role in the decision-making process.

\section{Objectives}

The aim of the study is to determine the extent of the women's participation and its effectiveness in different structures and decision-making processes of the Union Parishad. The study identified two specific objectives that are as follows 
(a) to portray the nature of participation and the associated problems faced by women in decision-making process at local level of the study area, and (b) to assess the state-of-art of transformation and changes in decision-making process by women in the study area.

\section{Methodology of the Study}

The present research followed an empirical way of investigating the nature and extent of women's participation in local government institution in which, direct field observations were taken from Union Parishad level. Moreover, to verify and resonate the field observation, extensive secondary literature was analysed in the study.

\section{Study area}

The present research randomly selected Rajshahi and Naogaon districts as the study area to analyse the extent of the participation of women in decision-making processes (Figure 1). A total number of 20 UPs have been selected from the two districts in which 9 UPs were selected from Rajshahi and the remaining 11 UPs have been selected from Naogaon districts. To incorporate diverse views, data were collected from 20 UPs covering North-west zone of Bangladesh.

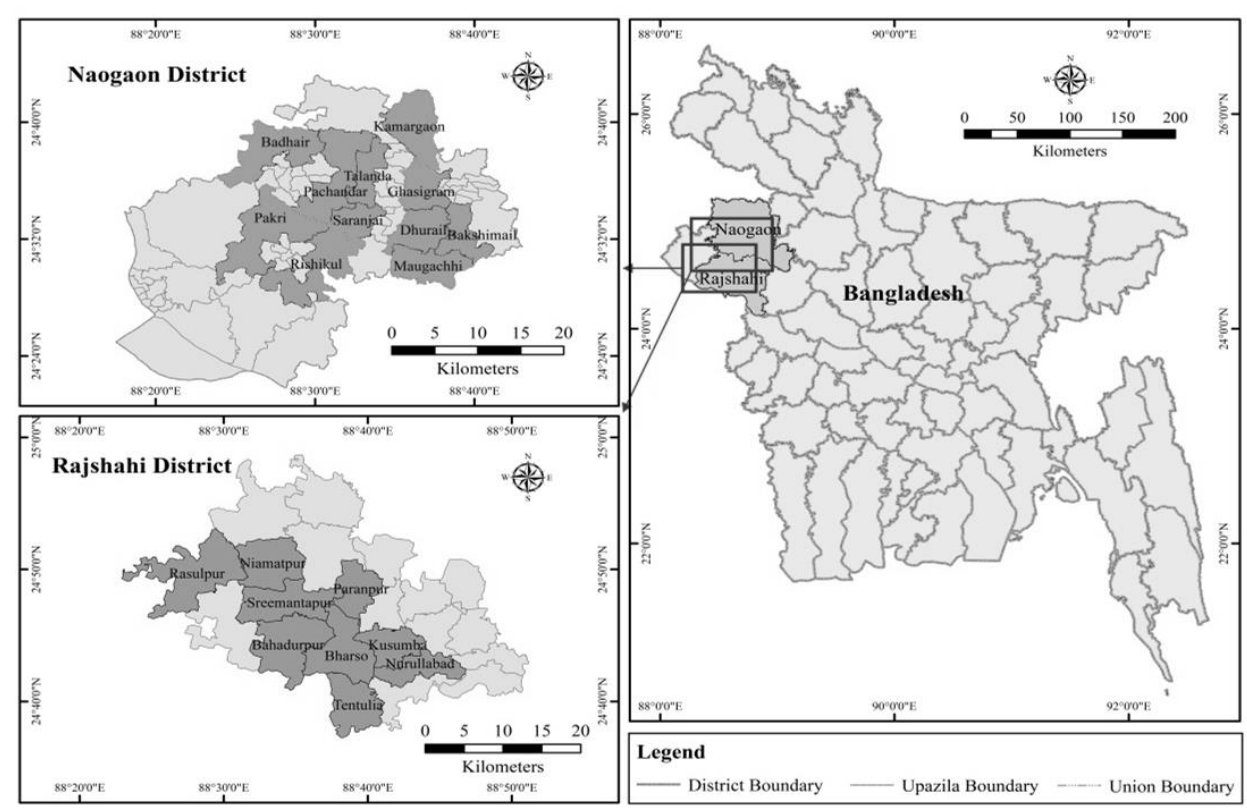

Figure 1: The location of the study sites (UPs) in Rajshahi and Noagoan districts of Bangladesh. 


\section{Methods and data}

To fulfil the objectives, the study followed both the qualitative and quantitative methods. The qualitative methods not only helped to unearth the research questions effectively but also facilitated to examine and narrate vibrant field experiences, multiple realities, the extent of the benefits and the gaps of women's participation in the decision-making process of Union Parishad. Authors' own observation gained through prolonged field experiences have also been incorporated in the present study.

A questionnaire survey has been conducted in 20 UPs of Rajshahi and Noagoan district to know the extent of the participation of women in decision making processes. Primarily, twenty UPs were selected through consultation with the District Commissioner (DC) and Upazila Nirbahi Officer (UNO), Local Government Engineering Department (LGED) officials, local NGOs, and officials of Asian Development Bank (ADB), Bangladesh Residential Mission (BRM). Necessary project documents, including project baseline, project reports, muster roles, and resolutions of the different meetings, contract agreement with contractors from Non-Government Organization (NGO), Local Government Engineer Department (LGED), and UPs have been collected and revised to understand the delivered activities. Primary data were collected directly from the field. To support primary data some secondary data were also used. Since the study was phenomenological in nature, data were arranged thematically. The respondents were interviewed independently with a sound rapport building, maintaining research ethics of mutual respect, do no harm and confidentiality so that they can feel free to share their life experiences and realities. Besides, some community members and leaders were also interviewed to understand their perspectives and crosscheck women's realities.

The total sample size was 380 comprising 279 respondents for questionnaire survey and 101 respondents for 8 FGDs and 11 KIIs. The questionnaire was the main instrument of the survey. Apart from face-to-face semi-structured questionnaire, checklists for Focus Group Discussion (FGDs), Key Informant Interview (KII) were utilized for discussion with women UP members, women beneficiaries of the development schemes and local elites (both men and women and often PIC members). Moreover, "Look-listen-learn" method was also utilized to understand the effectiveness of the participation with consideration of the 
research ethics. Moreover, elected men and women UP members, UP chairmen, the secretaries as well as women beneficiaries of the implemented schemes have been interviewed. The whole discussion of the FGDs and KIIs was recorded with the permission of the respondents and then transcription was arranged in English from Bengali notes. In line with the research questions, information was at that point organized into distinctive topical ranges through a rigorous process including detailed narratives. For analysing the essence and meaning of the textual descriptions obtained from the participants, the content analysis method was adopted using the relevant literature from research reports, books, journal articles through an exploratory search from library materials and online. Quantitative data was tabulated and analysed through SPSS and qualitative data was analysed in matrices. Moreover, considering the different meanings and implementation of the participatory, Arnstein's (1969) ladder of participation, has been adopted to assess the extent and effectiveness of the engagement in the different decision-making process of UP.

\section{Results and Discussion}

With a view to identify the nature of participation and the transformation of roles of women in decision-making processes at local level, the present study firstly assessed the competencies of women UP members compared to the men members in the study area. The level of education of men UP chairs and UP members is comparatively higher than that of women UP members. More than one half of the women UP members studied up to class eight only and $21 \%$ completed higher secondary education. Only about $5 \%$ of the women UP members can signature only and another $11 \%$ can simply read and write with very little or no formal education. In contrast, $60 \%$ of the men UP members have completed secondary to higher secondary and above level of education and the remaining $40 \%$ read up to class eight. Among the UP chairs, more than one-half completed secondary and higher secondary education, one third are graduate and one-eighth studied up to class eight. Hence, the UP chairs are in general better educated than UP members while the women UP members in general have low levels of education. Most of the women UP members (about 89\%) were engaged with household chores and remaining of them were related to salaried profession. On the other hand, about $50 \%$ of men UP members were involved in business followed by $40 \%$ and $10 \%$ involved in agriculture and salaried profession. 


\section{Nature of Participation and Associated Problems}

\section{Aspiration and the benefits of interest}

The present study shows that most of the UP representatives had low income. Only $11 \%$ of the women UP members had their own earning and not dependent on other family members such as husband, elder son whereas, $89 \%$ of them were home maker. However, family's choice and the decision were one of the important factors for the women representatives to participate in UP's election. As per observation and in-depth interview, it is reflected that almost all UP representatives (except a negligible number of them) participated in UP's election to gain financial benefits and use power in the community. They spent much more money than expected in the UP's election to win against their counterparts. Thus, they tried to regain and recover the election expenses. In many cases, family members (husband and elder sons) and relatives spent money on behalf of women representatives as a loan or an investment. Before elections, many women also committed to their family members and relatives to give them benefits (such as buying a motorcycle for husband or son, construction of a new building for family members, providing handsome money for husband's business or relative's business). After winning in the election, women representatives felt pressure to keep their commitment and resulted to engage them in manipulation and corruption of the projects and UP's activities. For instance, Social Safety Net (SSN) programs consider having a wide range of coverage and benefiting special target groups but, different forms of corruptions (estimated 15 to 17 percent) like a bribe, mal-targeting and receiving less than prescribed amounts are moderately affecting to the effectiveness of this program. Lack of transparency and social accountability from both supply and demand sides, weak and passive participation of local communities in the project implementation process directly or indirectly leaked out the system (Das \& Nahar, 2014).

\section{Technical exclusion of women in implementation of the projects}

The present study indicates that the participation of women in the implementation of the projects in UP level is very low compared to men. The UPs generally implement projects on Test Relief, Food for Work, 40 days' Work, LGSP, reserve allocation from Upazila and others. The study shows that during the survey period as per resolutions, the selected UPs implemented about 647 different projects whereas, about 178 women UP members (only about 27\%) were 
appointed as chairperson of Project Implementation Committees (PIC) of these projects. Resolutions of PIC formation were available for UP office particularly to LGSP, TR, $F F W$ including reserved allocation funded projects. As per documents, most of these projects had been implemented through contractors and different institutions such as school and Madrasah (religious institution). The survey found that almost all the LGSP and TA projects implemented by tender or procurement process. Although as per documents, percentage of women UP members of reserved seats as chairperson of PIC was $18 \%$ in TR, 30\% in FFW, $29 \%$ in 40 days works, $21 \%$ in LGSP, $34 \%$ in TA 7720-BAN and about $27 \%$ in other projects respectively (Table1); physical access of women UP members in implementation was negligible (about $12 \%$ of women UP members). Family members including husband, elder son or relatives also assisted the empowered women UP members to get allocation of the projects as well as implementation. Others $88 \%$ of women UP members were technically excluded to implement the project through negotiation between UP chairs and women members on benefit of interest. Moreover, physical presence of the contractors in infrastructure development was almost null. Albeit classical influential capture of development projects in Bangladesh including duplication and exclusion of the true poor beneficiaries is not a new finding, early literature of the 1980s found local influential as a hindrance to improvement, capture external development aid with maintaining patronage networks for individual gains (BRAC, 1983; Boyce, 1987). The present study proves technical exclusion of women representatives and the classical influential capture on development projects for individual benefits. For example, in the study area, the UP chairs and their faithful representatives or relatives authentically implemented the infrastructure development project for the personal benefits by the name of the contractors.

The study also found that UPs excluded the extreme poor, less-voiced, non-elites, less influential and opponent political identities to participate in project implementation. In particular, the majority of poor and women respondents stated that they did not have a contribution to the activities of the PIC.

The study also shows that UPs somehow (most probably corruption practice) managed the monitoring activities (both physical and financial) conducted by the Upazila administration, audit department of the government and private audit companies. 
Table 1: Percentage of chairpersons of PIC in development projects of the selected UPs.

\begin{tabular}{|l|c|c|c|c|c|c|}
\hline \multirow{2}{*}{ Types of projects } & \multicolumn{2}{|c|}{ Women } & \multicolumn{2}{c|}{ Men } & \multicolumn{2}{c|}{ Total } \\
\cline { 2 - 7 } & Number & Percentage & Number & Percentage & Number & Percentage \\
\hline LGSP & 46 & $21.10 \%$ & 172 & $78.90 \%$ & 218 & $100 \%$ \\
\hline 40 days & 37 & $29.37 \%$ & 89 & $70.63 \%$ & 126 & $100 \%$ \\
\hline TR & 11 & $18.03 \%$ & 50 & $81.97 \%$ & 61 & $100 \%$ \\
\hline Others & 14 & $26.92 \%$ & 38 & $73.08 \%$ & 52 & $100 \%$ \\
\hline FFW & 11 & $29.73 \%$ & 26 & $70.27 \%$ & 37 & $100 \%$ \\
\hline TA 7720 BAN & 59 & $33.52 \%$ & 117 & $66.48 \%$ & 176 & $100 \%$ \\
\hline Total & 178 & $27.51 \%$ & 469 & $72.49 \%$ & 647 & $100 \%$ \\
\hline
\end{tabular}

Source: Field survey, 2016.

\section{Substandard status and gender inequality}

The study shows that while considerable progress has been made in the election of women to local government (Union Parishad) positions in Bangladesh through the reservation of one-third of all seats reserved are not seen as having the same value as general ones. As well, once elected as women UP members, many women have found further obstacles as their positions are reserved and are unequal to men. They received comparatively lower benefits and opportunities in UP's functions than men UP representatives due to gender discrimination, politicization of UP chairmen and officials. A general tendency is the side-lining of women members (about 21\%) by the men members, UP chairmen and secretaries (about 79\%) and limitation of monitoring of local level government authority. They were unable to function properly of their duties and responsibilities because of gender exploitation, gender blind, non-cooperation, politicization, and centralization of power by both men UP representatives and officials. Furthermore, the reality is that women have juggled their local government role with their domestic schedules which also have considerably affected the performance of their duties and responsibilities in local government (Union Parishad) structures and decision-making processes.

\section{Quality and sustainability concern}

In the study area, in last UP election (2015-16), women members contested at all these levels of UP, but success or wining in different positions against contest of men counterparts is very negligible. In the last UP election, only $5 \%$ of women UP members, $15 \%$ of UP chairmen and about $10 \%$ of men UP members have been 
re-elected. On the other hand, $12 \%$ of women UP members and $20 \%$ of men UP members did not participate in election for second time due to frustration of UP's activities, business and non-cooperation of UP chairmen and influential UP members. Some of them replied that they were unsuccessful to recover their expenses of the last election (2011). Thus, they were not interested to take the risk of honour and invested money again. Some of the respondents of FGDs and KIIs replied that reasons of failure of the majority of the men and women UP representatives include (1) unskilful activities (2) lack of communication with the community after winning election (3) poor quality of implementing infrastructures (4) lack of honesty, misuse of fund and corruption (5) poor education (6) political identity (6) lack of leadership and (7) mismanagement of social safety net distribution.

Irony is that crores of Bangladeshi Taka (BDT) have been expended by the donors and government for capacity building of UP representatives with training, coaching and assets supports, but re-wining in election is very scanty. It is a question mark for development agencies to consider the strategy of the project implementation and the value of money of the project's impacts. It requires further study to find out the strategy where attention should give by the donor agencies and government to strengthen and institutionalizing the local government.

\section{State-of-art of Transformation}

\section{Positive changes of services}

While UPs have several problems to practice governance and inclusion of women, they have a long history of success to become an institution. The study shows that about $90 \%$ of the selected UPs have new building constructed by LGED. As per design, though there is a provision to allocate a separate toilet and room facilities for three women members and women visitors, UPs confirmed separate toilet facilities and rest room where donor driven projects are ongoing. Except donor driven projects, the study did not find any separate toilet and restroom facilities for women UP members and visitors. Moreover, as per observation, condition of the toilets was very unhygienic and sometimes men UP members also visit the women's toilet, although there is sticker "women's toilet". Negligence also has been observed in rest room allocation, many of the women's restroom also used as a warehouse. In two UPs, women restroom also used as gossiping room of UP chairs and men colleagues. The survey shows that in all 
project activities of all the selected UPs the women labours are receiving wages equal to men for equal works, but $70 \%$ of the UPs did not confirm the condition of equal wages for men and women Labours for the same types of works in the contractor's accord of the project.

It is evident in the literature that woman representatives of Union Parishad have fellow-feeling and special responsibility to represent the needs and interests of women (Waring, Greenwood, \& Pintat, 2000; Sawer, 2002). Women representatives participated more in community services (e.g., rural arbitration, mediation for violence against women, access to health facilities from the community clinic etc) at the local government (Johnson, Kabuchu, \& Kayonga, 2003). Moreover, women representatives have a greater sense of social and gender issues, well-being, and welfare of their communities (Drage, 2001). The study shows that the UPs have successfully mediated various social problems through rural arbitration (Salish) and activities of the village court. Presence of women members in the rural Salish has brought a positive change at the community level to help rural women to get the social justice. In recent times, when a woman became victims of physical assault by her husband, woman member can monitor and accordingly the charge can be framed by the Salish council with evidential proof. When poor women sought assistance regarding family feuds or violence against women, these women UP member helped them get social and legal support from relevant sources.

The present study shows that a positive change occurred in the resolution of social problems by the women UP members. About $55 \%$ of women UP members have a satisfactory understanding of conducting rural arbitration and village court, whereas the same percent of women UP members applied their knowledge and skills in the practical field. The activities undertaken include presence in arbitration, participation in debating of arbitration, following the process of village court, taking decision through consultation with other arbitrators. Fifty percent of the women UP members had effectively participated in rural arbitration in their election. They also replied that community arbitrators, victims and opponents had respected their opinions and decisions. Five percent of the women UP members had delegated power as arbitrator in rural arbitration and had shared the decisions and responsibilities to other members of arbitration team. Forty five percent of the women UP members replied that they are capable to govern the responsibilities of rural arbitration. They effectively resolved most of the conflicts related to women's issues included-family level quarrel, conflicts 
between husband and wife, dowry, separation, child marriage and violence against women. As per consultation with field team and checking of documents, Women UP members were busy one day per week for operating village court and maintaining the related process documenting. Most of the time, UP chairs along with some UP members resolved the dispute between defender and accused (against and for) in the UP premises. In some cases, they involved parties (defender and accused) did not follow the notice of hearing.

\section{Progressive transformation and manipulation}

The study shows that the selected UPs activities were donor's driven rather than application of the practice of local government act. However, awarded money from the donor's projects had encouraged the selected UPs to meet some of the criteria (allocation of separate toilet facility for women in UP complex, conduction of some of the meeting of the SC, PIC and Ward Shava). Selected UPs tried to meet the criteria of the donor's projects to get the award money. The study shows that selected UPs implemented a project title "Technical Assistance (TA) -7720-BAN: Institutionalizing Women's Benefits from Rural Infrastructure Initiatives" with assistance of a national NGO, funded by the Japan Fund for Poverty Reduction (JFPR) and managed by ADB and LGED. This project implemented from May 2012 to March 2016. Within this project period, about $100 \%$ of the UP representatives received skill training on "roles and responsibilities of UP representatives and on the functions of UP" including SC meetings, PIC, tax collection procedures, budget preparation and declaration, project preparation \& implementation and conduction of the Ward Shava. A series of interventions had been done for awareness raising and capacity building of the UP representatives to active the UP's functions with the effective involvement of women. Like TA project, selected UPs received training on similar types of activities with duplication of the project activities from different donor's projects and government institutes.

As per UP Act 2009, SC meetings of UP would be held bi-monthly, the meeting minutes to be prepared and shared in the UP-Council meeting for taking appropriate actions. The UP-Council even has the authority to send reports to the service delivery departments (agriculture, health, family planning, fisheries, and livestock) for negligence of duties of the officials posted at UP level. The present study shows that knowledge about standing committee meetings of both men and women UP representatives increased by $64 \%$ compared to previous states. The 
study shows that all 20 UPs ensured 1/3 quota of women both as chairperson and member of the SC, delegation of powers to women members in the decisionmaking process as per UP Act-2009. Moreover, about $77 \%$ of UP representatives and $72 \%$ of women UP members had knowledge of monthly meeting, including process of monthly meetings, circulation of notice, following quorum, designated chairperson of the meeting, agenda, resolution writing and decision making. In addition, they had taken initiatives to implement important decisions of the SCs, such as, stopping child marriage and violence against women, planting trees, birth, and death registration, assessing tax and help with the collection, visiting girls' schools and community clinics and conducting courtyard meetings on various awareness raising issues at the community level.

The quantitative study shows that as a mandate of the TA-project of ADB, UP members had conducted ward meeting (Ward Shava) in 33\% of the electoral Wards whereas about $60 \%$ of women UP members had applied their knowledge and skills in conduction of Ward Shava, observing fulfilment of quorum of the meeting, informing voters and community through mass publicity campaign, writing resolution, ensuring required percentage of attendance of women voters.

\section{Recommendations}

The study contributes to the current literature by adding examples of failure and successful attempts of institutionalizing Union Parishads in a sustainable manner. A higher degree of tokenism in the Standing Committee, Project Implementation Committee and Ward level meetings were found. Deep inequalities of power and imbedded in UPs, conflict of interest, lack of transparency and accountability about project implementation were observed. Besides, top-down system of the project implementation and UP's management remained the centralized power of UP chairmen. Therefore, the study has drawn some recommendations to make the women's participation effective at the UP level. Attention should be given to the democratic decentralization at the Ward level. A further study might be important to find out the gaps of the project implementation considering the impacts, the value of money, sustainability, social inclusion, leakage, institutionalization, governance practice, transparency, and accountability. Political influence sometimes increased leakage and malpractice of the UPs. Thus, effective, and regular monitoring followed by the Local Government Act-2009 is necessary by the designated officers from Upazila level. The study observed that biased auditing system and corruption by the 
auditors encouraged the UPs to leakage the project and misuse of the fund. A positive attitude of men representatives and inspiration of UP chairmen is crucial to sustaining women's participation. The power is centralized by the UP chairman. However, it may be decentralized to empower the vice-chairmen positions through a democratic, transparent, and accountable way. Moreover, women representatives extremely depended on UP secretary for resolution writing of the meetings and preparation of schemes' proposal and hence they require to apply continues learning by assisting them in resolution writing by NGOs and the educated members of the committees. The resolutions writing and follow up should be mandatory. Effective monitoring by Upazila administration extensively minimized the leakage. A clear penalty and punishment should be included in the UP's Act-2009 to reduce corruption. It is required to provide no allocation if UPs do not active the committees and maintain the processes. The community-based plan, infrastructure development plan with Global Positioning System (GPS) data and digitalization of the process of project implementation might be factual to ensure successful implementation of infrastructure-related projects with transparency and accountability. Formation of the committees should be democratic and transparent, and conduction of the meetings should be monitored regularly to ensure accountability. Women representatives, in some cases, failed to conduct the meetings due to constraints of finance, UP's demeanour and practice, thus minimum $2 \%$ of budgetary allocation needs to be provided from UP's own fund for conducting different type meetings. Refreshment and minor travel expenses for the UP representatives in the meetings might be encouraged to improve the situation.

\section{Conclusion}

Women's participation in LGIs had been promoted since 1976 as a means to empower the women at the grassroots level. Most importantly, several studies have pointed to shortcomings and confinements of the Local Government Institutes (LGIs) including political engagement of women, which has given a path to the government and donors to debate about the decentralization of the power of UP chairs. However, the present study contributes to the recent literature by drawing examples of success and failure attempts of participation of woman representatives to the diverse activities of Union Parishad and its decision-making structures and process with transparent, and accountable manner. 


\section{References}

Alam, B. A. (1995). Women in Local Government: Profiles of six Chairmen of Union Parishads, The Journal of Local Government, 16(1), 39-50.

Ahmed, T. (2003). Gender Dimensions in Local Government Institutions. Dhaka: Nari Uddug Kendra.

Akhter, S., \& Chowdhury, A. K. (2005). Bangladeshe Panchabarsik Parikalpanae Nari: Ekti Parjalochana (Women in the Five-Year Plans of Bangladesh: An Overview), The Chittagong University Journal of Social Science, 22(1), 21-30.

Arnstein, S.R. (1969). A Ladder of Citizen Participation, Journal of the American Planning Association, 35(4), 216-224.

Asian Development Bank (ADB). (2001). Women in Bangladesh: Country Briefing Paper. Manila, Philippines: Asian Development Bank. Retrieved from http://www.adb.org/ documents/women-bangladesh-country-briefing-paper (Accessed on March 5, 2019).

Bangladesh Bureau of Statistics (BBS). (2011). Bangladesh Statistical Yearbook 2011. Dhaka: BBS.

Banglapedia. (2019). National Encyclopaedia of Bangladesh. Retrieved from http:// www.banglapedia.org/httpdocs/HT/L_0122.HTM (Accessed on December 20, 2019).

Boesche, R. (2003). Kautilya's Arthaśāstra on War and Diplomacy in Ancient India, The Journal of Military History, 67(1), 9-37.

Cohen, J. M., \& Uphoff, N. (1977). Rural Development Participation: Concepts and Measures for Project Design, Implementation and Evaluation. New York: Cornell University.

Das, M. (2016). An Evaluation Report: Support to Local Government Engineering Department (LGED) in Institutionalizing Women's Benefits from Rural Infrastructure Initiatives, an unpublished report, Dhaka: ADB and Shushilan.

Das, M., \& Nahar, N. (2014). Participatory Safety Net Management: A Case Study on Vulnerable Char Areas of Bangladesh. Social Science Review, 31(2), 243-258.

Drage, J. (2001). Women in Local Government in Asia and The Pacific: A Comparative Analysis of Thirteen Countries, Report for the ESCAP. Retrieved from http://www.citieslocalgovern ments.org/101a/upload/docs/women-in-urban-local-government (Accessed on March 5, 2019).

Haque, M.S. (2003). Reinventing Governance for Performance in South Asia: Impacts on Citizenship Rights. International Journal of Public Administration, $26(8$ \& 9), 941-964.

Jahan, M. (1997). The Changing Structure of Local Government in Bangladesh: An Overview. Administration, Communication and Society, 1(1), 91-105.

Jazairy, I. (1989). Assessing Participatory Development: Rhetoric versus Reality. Westview Press: Rome.

Johnson, D., Kabuchu, H., \& Kayonga, S. V. (2003). Women in Ugandan Local Government: The Impact of Affirmative Action. Gender and Development, 11(3), 8-18. Retrieved from https://doi.org/10.1080/741954365 (Accessed on March 9, 2019).

Karmaker, R. (2006). New Steps promoting gender equality human rights and good governance. Dhaka: Steps towards Development.

Khan, M. M., \& Fardaus, A. (2006). Women Participation and Development in Local Government: Bangladesh Union Parishad Perspective. Asian Affairs, 1(29), 73-74.

Mahtab, N. (2007). Women in Bangladesh from Inequality to Empowerment. Dhaka: $\mathrm{AH}$ Development Publishing House. 
Meldon, J., Kenny, M., \& Walsh, J. (2004). Local Government, Local Development and Citizen Participation: Lesson from Ireland. In R. W. R. Lovan, M. Murry, \& R. Shaffer (Eds.), Participatory Governance: Planning, Conflict Mediation and Public Decision Making in Civil Society. Farnham: Ashgate Publishing.

Qadir, S. R. (1995). Women in Politics and Local Bodies in Bangladesh, Women in Politics and Bureaucracy. Women for Women, 16(1), 27-38.

Rahman, M. M. (2000). Politics and Development of Rural Local Self-Government in Bangladesh. Delhi: Devika Publication.

Rahman, M. M. (2015). Contributions of Women's Participation in the Local Government of Bangladesh. Sociology Mind, 5(3), 200-212. Retrieved from http://dx.doi.org/10.4236/ sm.2015.53018 (Accessed on March 9, 2019).

Roberts, N. (2004). Public Deliberation in an Age of Direct Citizen Participation. American Review of Public Administration, 25(2), 119-136. Retrieved from http://dx.doi.org/ 10.1177/0275074004269288 (Accessed on March 9, 2019).

Sawer, M. (2002). The Representation of Women in Australia: Meaning and Make-Believe. Parliamentary Affairs, 55(1), 5-18. Retrieved from http://dx.doi.orag/10.1093/parlij/55.1.5 (Accessed on March 9, 2019).

Siddiqui, K. (1994). Local Government in Bangladesh. Dhaka: University Press Limited.

Talukdar, R. I. (2009). Rural Local government in Bangladesh. Legacy and History, Dhaka: Osder Publications.

Waring, M., Greenwood, G., \& Pintat, C. (2000). Politics: Women's Insights. Inter-Parliamentary Union, Geneva, retrieved from https://www.marilynwaring.com/publications/womensinsight.asp, (Accessed on March 9, 2019).

White, S. A. (1994). The Concept of Participation: Transforming Rhetoric to Reality. In White, S. A., Nair, K. S. and Ascroft, J. (Eds.), Participatory Communication: Working for Change and Development. London: Sage. 